\title{
Characterization of three atmospheric aerosol episodes at a coastal site in China: Implications for regional transport of air pollution
}

\author{
F. Adams and X.D. Liu ${ }^{1}$ \\ University of Antwerp, 2610 Wilrijk, Belgium \\ ${ }^{1}$ Chinese Research Academy of Environmental Sciences, Beijing 100012, China
}

\begin{abstract}
Size-selective atmospheric aerosol samples, collected between March 28 and April 82002 in Changdao, a small island in eastern China, were characterized by analysis of elements, ions, organic and elemental carbon, lead isotopes, and single particles. On the basis of compositional differences and remote sensing information, three distinct aerosol pollution episodes were identified. The first was dominated by fine particles with a substantial contribution from biomass burning emissions and industrial lead-containing particles from inland China at least 800 kilometers away. The second was characterized by coarse and aged secondary calcium sulfate particles and primary calcium sulfate particles from local industrial sources as well as windblown mineral dust. The third was a typical Asian Dust event with a source region on the border between China and Mongolia at a distance of around 1000 kilometers. Abundant sulfate particles found at the beginning of the Asian Dust event were predominantly ammonium sulfates in the fine fraction and calcium and ammonium sulfates in the coarse fraction. The major portion of the pollutants and the dust front of the event arrived in separate air masses. Although the three events occurred in quick succession they were quite different in terms of size distribution, chemical composition, sulfate speciation, source types, and source geographic locations. Biomass burning, industrial emission, coal combustion, and mineral dusts were identified as sources of the Asian continental outflow.
\end{abstract}

\section{Introduction}

With a rapidly growing economy, the concentration of air pollutants in general and air particulates in particular remain at a high level in Chinese coastal regions. The situation becomes increasingly severe and complicated when anthropogenic emissions containing a variety of carbonaceous compounds and inorganic ions are mixed with mineral dusts originated from arid regions of North China and Mongolia. It has been frequently observed by remote sensing techniques that Chinese coastal areas were covered by haze resulting from Asian dust clouds. Combined with the atmospheric circulation pattern, dust inevitably exerts its impact to the downwind regions in northeast Asia and the North Pacific. Along the path of the Asian continental outflow, a number of aerosol studies were carried out e.g. in Yellow Sea at Cheju Island [1], the East China Sea, the Sea of Japan, and the North Pacific Ocean [2-5]. Only a few studies concern the Chinese side of the Yellow Sea [6,7].

In recent years an increasing number of studies have been devoted to the study of specific pollution episodes for gaining insight into how they start and evolve and to obtain a better understanding of transport and transformation processes during the episode [8-11]. 


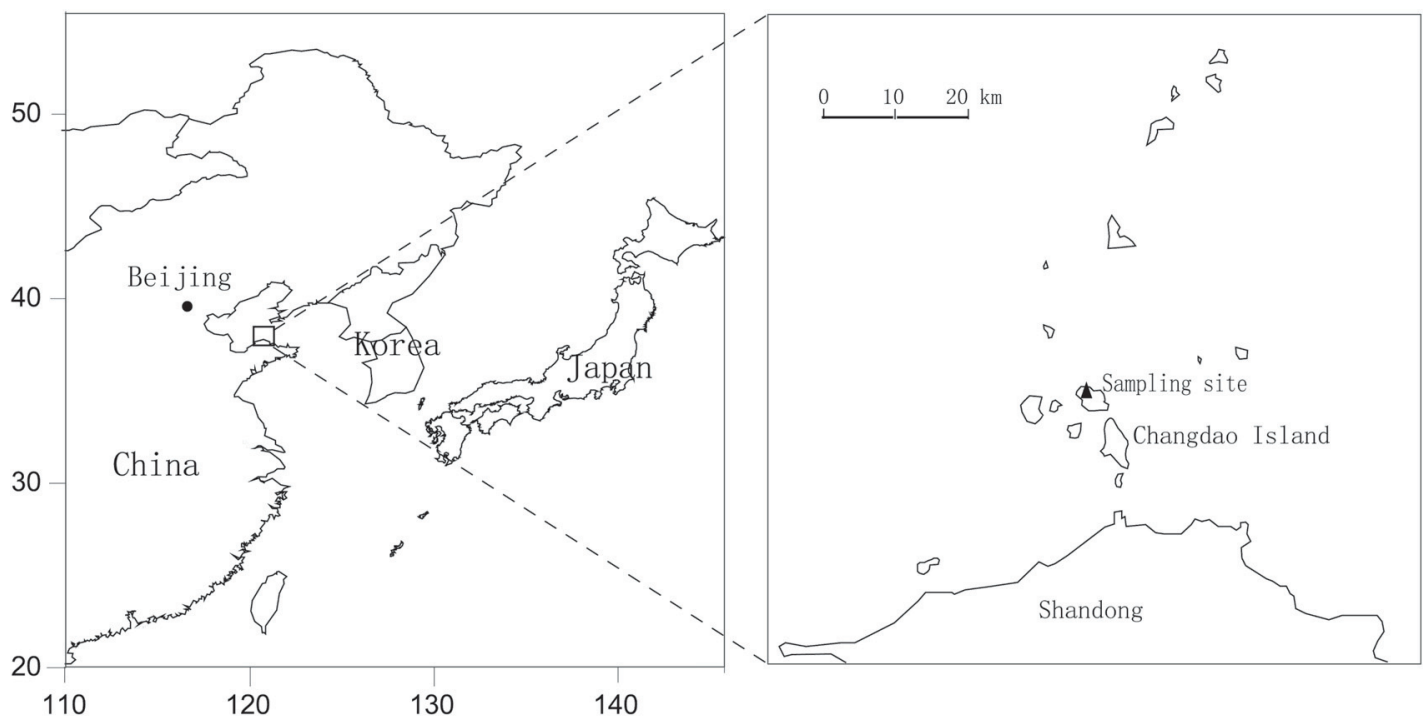

Fig. 1. Map of sampling site in Changdao Island.

For detailed studies of pollution episodes chemical and physical characterization needs to be considerably more comprehensive than for routine monitoring. High time-resolution sampling such as provided by real-time measurement systems coupled with comprehensive analysis is necessary, while meteorological and remote sensing information is essential for the study of regional impact. Chemical analysis provides aerosol composition and size-distribution information while the remote sensing provides a wide regional view yielding data on long-range transport. Isolated sites with low local emissions are preferable to allow the observation of regional representative contributions [12].

This study reports on the results of a sampling campaign to study the aerosol chemistry in Changdao, a small island to the north of the coastal province of Shandong, China. It is a site in the transport path of the Asian continental outflow, being surrounded by populated continental landmasses on the north, west and south, while facing the Yellow Sea to the east. Fine (PM2) and coarse (PM2-10) fractions of the atmospheric aerosol were collected. Analysis included elements, ions, carbon content, lead isotopes as well as particle classes using single particle analysis techniques. Three aerosol episodes were identified and their sources, geographical origin and its implications for regional transport of air pollution were investigated on the basis of combined ground-level observations and meteorological and remote sensing information.

\section{Experimental}

\subsection{Sampling campaign}

Changdao Island $(37.91 \mathrm{~N}, 120.73 \mathrm{E})$ consists of a group of seven small islands to the north of the coastal province of Shandong (Eastern China) and on the divide between the Bo Sea and Yellow Sea (see Figure 1). The sampling site is on the north summit of North Changshan Island, 72 meters above sea level. Thus, this receptor site is affected by one region or another depending upon wind history and direction. There are no significant local emission sources on the islands. The location is, hence, quite appropriate for the purpose of this study.

The sampling campaign lasted for 11 days from March 28 to April 8, 2002. Two dichotomous samplers using SFU (Stacked Filter Unit) were used to collect fine (PM2) and coarse (PM210) fractions of the aerosol [13]. Coarse aerosols were collected on polycarbonate membranes (Nuclepore) while fine aerosols were collected on polycarbonate membranes in one sampler and on quartz fiber filters in the other. The Nuclepore filters were used for subsequent analysis of 
a number of elements, ions and single particle analysis, whereas the quartz fiber filters were analyzed for organic carbon (OC) and elemental carbon (EC). The $2.2 \mu \mathrm{m}$ cutoff was obtained by using $8 \mu \mathrm{m}$ Nuclepore filters for sampling of the coarse fraction. The sampling flow rate was 16.7 liters per minute [13]. All aerosol samples were collected for 24 hours starting from 9 am.

\subsection{Bulk analysis}

A quarter of the loaded Nuclepore filters were digested with $\mathrm{HNO}_{3}$ and $\mathrm{H}_{2} \mathrm{O}_{2}$. Al, $\mathrm{Ca}, \mathrm{Mg}, \mathrm{K}, \mathrm{Na}$ and $\mathrm{S}$ were determined with ICP-AES (IRIS Advantages, TJA Solutions, Boston, USA) while $\mathrm{Sc}, \mathrm{Ti}, \mathrm{V}, \mathrm{Ni}, \mathrm{Zn}, \mathrm{As}, \mathrm{Br}, \mathrm{Sb}$ and $\mathrm{Pb}$ were determined with inductively coupled plasma mass spectrometry (ICP-MS, PQ ExCell, TJA Solutions, Boston, USA). The soil reference material (GSS-1) was analyzed in parallel with the aerosol samples as a quality control measure. The results obtained for this sample were within the uncertainty range of the certified values.

Half of the Nuclepore filters were extracted with de-ionized water for ion analysis with ion chromatography (Dionex, 2000i/sp, Sunnyvale, USA). Eight ions were determined: sulfate, nitrate, chloride, ammonium, sodium, potassium, magnesium, and calcium. Ion balances were checked for anions and cations.

$\mathrm{OC}$ and EC were determined using a laboratory 2-step thermal procedure. Carbon contents were obtained with a carbon-hydrogen-nitrogen analyzer (MT-5 YANACO New Science Corporation, Tokyo, Japan) using helium with $8 \%$ oxygen as a carrier gas [14]. At a combustion temperature of $450^{\circ} \mathrm{C}$ the $\mathrm{OC}$ content is determined directly. When the combustion temperature is set at $950^{\circ} \mathrm{C}$ the sum of $\mathrm{OC}$ and $\mathrm{EC}$ (total carbon, TC) is determined after removal of carbonates by adding diluted $\mathrm{HCl}$. The EC content is then obtained by subtraction of the two measurements. The precision of the method in terms of the standard deviation for OC and $\mathrm{EC}$ is $0.33 \%$ and $0.60 \%$ and the detection limit is $5 \mu \mathrm{g} \mathrm{C}[15,16]$. Inter-laboratory comparison was performed to evaluate the accuracy of this method by measuring the same urban aerosol samples. The measurements were in good agreement with those obtained from the NIOSH thermal-optical method using a Sunset Laboratory instrument [17]. Based on 10 aerosol samples, the ratio was 1.03 for TC, 1.05 for OC and 0.92 for EC. As filter blank, $2 \mu \mathrm{g} \mathrm{C}$ of OC was subtracted for the aerosol samples, while the EC blank was lower than the detection limit and was neglected.

\subsection{Isotopic measurements}

Lead isotopic ratios were measured in triplicate with a double focusing magnetic sector field ICP-MS (ELEMENT Finnigan-MAT) for obtaining the average lead isotope ratio and its relative standard deviation. The NIST SRM 981 certified reference material was measured after every five aerosol samples to calibrate the isotope ratio data. The relative standard deviation of three measurements was less than $0.3 \%$ for ${ }^{206} \mathrm{~Pb} /{ }^{207} \mathrm{~Pb}$ and $0.5 \%$ for ${ }^{208} \mathrm{~Pb} /{ }^{206} \mathrm{~Pb}[18]$. The ratio of ${ }^{206} \mathrm{~Pb} /{ }^{207} \mathrm{~Pb}$ was used as its precision is superior to that of ${ }^{208} \mathrm{~Pb} /{ }^{206} \mathrm{~Pb}$ and ${ }^{204} \mathrm{~Pb} /{ }^{207} \mathrm{~Pb}$.

\subsection{Individual particle analysis}

Sections of each 47-mm diameter Nuclepore filter sample were mounted on electron microprobe stubs and vacuum-coated with a carbon layer of $40 \mathrm{~nm}$. The individual particles were analyzed with a JEOL JSM-6300 scanning electron microscope (SEM, Jeol, Tokyo, Japan) equipped with an annular backscattered electron detector and an energy-dispersive Xray detection system (PGT, Middleton, USA). The $\mathrm{Si}(\mathrm{Li})$ detector with a Be window provided detection for elements with $\mathrm{Z} \geq 11$. An electron accelerating voltage of $20 \mathrm{kV}$ was used for the fine particles and of $25 \mathrm{kV}$ for the coarse particles, while the beam current was always set to $1 \mathrm{nA}$. The magnification was 3000 for the fine and 1000 for the coarse particles and the minimum particle diameter to be detected was set to $0.5 \mu \mathrm{m}$ and $0.1 \mu \mathrm{m}$ for the coarse and fine particles. 
Table 1. Concentration $\left(\mu \mathrm{g} \mathrm{m}^{-3}\right)$ and ratio of fine and coarse particle fractions.

\begin{tabular}{|c|c|c|c|c|c|c|}
\hline & $\mathrm{PM}_{2}$ & $\mathrm{PM}_{2-10}$ & $\mathrm{PM}_{10}$ & $\mathrm{~F} / \mathrm{C}$ & Air mass characteristics & $\begin{array}{l}\text { Episodes } \\
\text { identified }\end{array}$ \\
\hline$\overline{\text { March } 28}$ & 22 & 36 & 58 & 0.61 & $\begin{array}{l}\text { From surrounding areas } \\
\text { and ocean }\end{array}$ & \\
\hline March 29 & 31 & 38 & 69 & 0.82 & & \\
\hline March 30 & 56 & 44 & 100 & 1.27 & From inland China & $1^{\text {st }}$ episode \\
\hline March 31 & 25 & 185 & 210 & 0.14 & $\begin{array}{c}\text { From inland areas } \\
\text { of North China }\end{array}$ & $2^{\text {nd }}$ episode \\
\hline April 1 & 32 & 154 & 186 & 0.21 & & \\
\hline April 2 & 26 & 119 & 145 & 0.22 & & \\
\hline April 3 & 15 & 75 & 90 & 0.20 & From Northeastern China & \\
\hline April 4 & 18 & 94 & 112 & 0.19 & & \\
\hline April 5 & 9 & 27 & 36 & 0.33 & Oceanic origin & \\
\hline April 6 & 54 & 286 & 340 & 0.19 & From northwest direction & $\begin{array}{l}3^{\text {rd }} \text { episode, } \\
\text { Asian dust event }\end{array}$ \\
\hline April 7 & 49 & 394 & 443 & 0.12 & & \\
\hline \multicolumn{7}{|c|}{ Statistics for non-Asian dust event (March 28-April 5) } \\
\hline Mean & 26 & 86 & 112 & 0.44 & & \\
\hline SD & 13.5 & 57 & 58 & 0.39 & & \\
\hline $\mathrm{RSD} \%$ & 52 & 66 & 52 & 87 & & \\
\hline
\end{tabular}

* SD: standard deviation; RSD: relative standard deviation.

Automated measurements of elemental intensities and particle shape and dimensions data were made using particle recognition and characterization software. A preset number of 500 particles were analyzed for each sample. Particles were classified into different particle groups according to their chemical composition using cluster analysis software and the particle number abundance was calculated for different particle groups. Details on our automated particle analysis procedures and software package can be found elsewhere $[19,20]$. In this study a total of 11,000 particles were measured in 22 samples.

\subsection{Other data}

The meteorological data from the Chinese National Meteorological Information Center were used. Backward trajectories were produced using the isentropic vertical motion approach in the HYSPLIT4 (HYbrid Single-Particle Lagrangian Integrated Trajectory) model with data from NOAA [21]. Using data of TOMS on the Earth Probe of NASA, information on the Aerosol Index over East Asia during March and April 2002 was obtained. The Aerosol Index is particularly useful for observing biomass burning episodes and mineral dust events [22,23].

\section{Results and discussion}

\subsection{General description}

There was no precipitation during the sampling campaign (March 28 to April 8, 2002). During the first two days the air mass moved over the Shandong peninsula from the surrounding ocean. From March 30 to April 2 westerly winds dominated and air mass advected from inland areas of North China (Hebei and Shandong provinces). From April 3 to 4, the air mass came from the north, traveling over Northeast China and Korea and finally the Bo Sea and the Yellow Sea. The air mass of April 5 (the cleanest day of the sampling campaign, lowest PM) was of oceanic origin, coming from the Yellow Sea and the Japan Sea. The last two days, April 6 and 7, with overwhelmingly westerly wind and the highest PM, were characteristic for an Asian Dust event. Among those days, two periods (March 31-April 2 and April 6-7) could be readily described as aerosol episodes on the basis of elevated PM10 concentrations of more than $140 \mu \mathrm{g} \mathrm{m}^{-3}$. 
Table 2. Elemental concentration $\left(\mu \mathrm{g} / \mathrm{m}^{3}\right)$ and ratio of fine particles $\left(\mathrm{PM}_{2}\right)$.

\begin{tabular}{lccccccccccc}
\hline & $\mathrm{Al}$ & $\mathrm{Ti}$ & $\mathrm{Ca}$ & $\mathrm{Mg}$ & $\mathrm{S}$ & $\mathrm{Zn}$ & $\mathrm{Pb}$ & $\mathrm{Al} / \mathrm{Ti}$ & $\mathrm{S} / \mathrm{Ti}$ & $\mathrm{Zn} / \mathrm{Ti}$ & $\mathrm{Pb} / \mathrm{Ti}$ \\
\hline March 28 & 0.27 & 0.02 & 1.15 & 0.19 & 1.87 & 0.06 & 0.11 & 15 & 101 & 3.2 & 6.1 \\
March 29 & 0.15 & 0.01 & 0.62 & 0.17 & 3.56 & 0.06 & 0.1 & 12 & 295 & 5.3 & 8.4 \\
March 30 & 0.28 & 0.01 & 1.48 & 0.2 & 6.36 & 0.25 & 0.81 & 24 & 530 & 20 & 68 \\
March 31 & 0.4 & 0.02 & 1.97 & 0.28 & 1.44 & 0.07 & 0.26 & 22 & 80 & 3.8 & 14 \\
April 1 & 0.91 & 0.03 & 2.57 & 0.56 & 1.52 & 0.06 & 0.09 & 28 & 46 & 1.7 & 2.8 \\
April 2 & 0.65 & 0.03 & 1.86 & 0.39 & 1.25 & 0.06 & 0.13 & 22 & 42 & 2.1 & 4.3 \\
April 3 & 0.21 & 0.02 & 0.83 & 0.19 & 1.06 & 0.08 & 0.04 & 13 & 65 & 4.6 & 2.5 \\
April 4 & 0.37 & 0.02 & 1.12 & 0.18 & 1.44 & 0.09 & 0.06 & 18 & 70 & 4.5 & 3.0 \\
April 5 & 0.07 & 0.01 & 0.68 & 0.11 & 0.88 & 0.06 & 0.02 & 6.8 & 92 & 5.9 & 1.8 \\
April 6 & 0.41 & 0.02 & 0.96 & 0.21 & 6.96 & 0.09 & 0.04 & 17 & 295 & 3.7 & 1.6 \\
April 7 & 2.0 & 0.05 & 2.5 & 0.90 & 0.41 & 0.04 & 0.01 & 40 & 8.2 & 0.9 & 0.2 \\
Statistics for non-Asian dust event (March 28-April 5) & & & & \\
Mean & 0.37 & 0.02 & 1.36 & 0.25 & 2.15 & 0.09 & 0.18 & 19.6 & 114 & 4.6 & 9.6 \\
RSD \% & 71 & 42 & 49 & 55 & 82 & 70 & 136 & 34 & 143 & 124 & 220 \\
\hline
\end{tabular}

Table 3. Elemental concentration $\left(\mu \mathrm{g} / \mathrm{m}^{3}\right)$ and ratio of coarse particles $\left(\mathrm{PM}_{2-10}\right)$.

\begin{tabular}{lccccccccccc}
\hline & $\mathrm{Al}$ & $\mathrm{Ti}$ & $\mathrm{Ca}$ & $\mathrm{Mg}$ & $\mathrm{S}$ & $\mathrm{Zn}$ & $\mathrm{Pb}$ & $\mathrm{Al} / \mathrm{Ti}$ & $\mathrm{S} / \mathrm{Ti}$ & $\mathrm{Zn} / \mathrm{Ti}$ & $\mathrm{Pb} / \mathrm{Ti}$ \\
\hline March 28 & 0.83 & 0.03 & 3.3 & 0.6 & 1.4 & 0.06 & 0.09 & 28 & 45 & 2.0 & 3.0 \\
March 29 & 0.77 & 0.03 & 3.2 & 0.6 & 2.3 & 0.06 & 0.09 & 26 & 78 & 2.0 & 3.0 \\
March 30 & 1.1 & 0.05 & 6.3 & 0.7 & 2.2 & 0.14 & 0.26 & 22 & 44 & 2.8 & 5.2 \\
March 31 & 4.2 & 0.12 & 16.8 & 2.6 & 5.2 & 0.24 & 1.2 & 35 & 43 & 2.0 & 9.8 \\
April 1 & 4.0 & 0.13 & 13.4 & 2.7 & 5.2 & 0.17 & 0.2 & 30 & 40 & 1.3 & 1.5 \\
April 2 & 6.3 & 0.22 & 15.2 & 3.4 & 6.3 & 0.16 & 0.15 & 29 & 28 & 0.7 & 0.7 \\
April 3 & 1.6 & 0.06 & 4.9 & 1.3 & 2.0 & 0.13 & 0.13 & 27 & 34 & 2.2 & 2.2 \\
April 4 & 1.8 & 0.09 & 5.9 & 1.2 & 2.5 & 0.11 & 0.15 & 21 & 28 & 1.2 & 1.7 \\
April 5 & 0.2 & 0.01 & 1.1 & 0.3 & 0.7 & 0.05 & 0.02 & 20 & 72 & 5.0 & 2.0 \\
April 6 & 9.0 & 0.17 & 9.2 & 4.1 & 3.7 & 0.1 & 0.05 & 53 & 22 & 0.6 & 0.3 \\
April 7 & 12.8 & 0.32 & 13.1 & 6.1 & 1.8 & 0.08 & 0.03 & 40 & 6 & 0.3 & 0.1 \\
Statistics for non-Asian dust event (March 28-April 5) & & & & \\
Mean & 2.3 & 0.08 & 7.8 & 1.5 & 3.1 & 0.12 & 0.25 & 26 & 46 & 2.1 & 3.2 \\
RSD \% & 88 & 80 & 74 & 75 & 63 & 50 & 141 & 18 & 38 & 58 & 86 \\
\hline
\end{tabular}

In Table 1, PM10 and fine (PM2) and coarse (PM2-10) particle concentrations and the fine to coarse ratio $(\mathrm{F} / \mathrm{C})$ are listed. The April 6-7 period was part of typical Asian Dust event that affected a huge land area of China and East Asia [24-26] characterized by a high coarse particle concentration. Samples collected in the period March 28 to April 5 were identified as non-Asian Dust aerosols; their mean concentration and standard deviation were used for comparison with the Asian Dust samples. The fine aerosol concentration was high on March 30 and the visibility was concurrently much deteriorated, indicating a pollution episode caused by fine particles.

Elemental composition and ionic species data for fine and coarse aerosol samples are presented in Tables 2 to 5. For the seven elements presented in Tables 2 and 3, Al and Ti are typical crust derived elements, they appeared with the highest concentration during the Asian Dust event in both the fine and the coarse fractions. The alkaline earth elements, e.g. Ca had the highest concentration from March 31 to April 2, particularly in the coarse fraction. Ca and $\mathrm{Mg}$ have both natural and anthropogenic sources and are prone to react with acidic gaseous pollutants. The data on the ions in Tables 4 and 5 indicated sulfate as the accompanying anion species to the alkaline earth elements. Typical heavy metals originating from anthropogenic sources such as $\mathrm{Pb}$ and $\mathrm{Zn}$, had peak values in the fine aerosol on March 30 and in coarse aerosol on March 31. These dates also featured high anion concentrations for sulfate, nitrate and chloride as well as a high potassium concentration, particularly in the fine fraction. Although their time interval were very short, three aerosol episodes identified appeared to have 
Table 4. Ion concentration and anion/cation ratio of fine particles $\left(\mathrm{PM}_{2}\right)$.

\begin{tabular}{|c|c|c|c|c|c|c|c|c|c|c|c|}
\hline & \multicolumn{10}{|c|}{ Equivalent concentration (unit: neq $/ \mathrm{m}^{3}$ ) } & \multirow[t]{3}{*}{ Anion/cation ratio } \\
\hline & \multicolumn{4}{|c|}{ Anion } & \multicolumn{6}{|c|}{ Cation } & \\
\hline Start date & $\mathrm{Cl}^{-}$ & $\mathrm{NO}_{3}^{-}$ & $\mathrm{SO}_{4}^{2-}$ & Sum & $\mathrm{Ca}^{2+}$ & $\mathrm{Mg}^{2+}$ & $\mathrm{K}^{+}$ & $\mathrm{Na}^{+}$ & $\mathrm{NH}_{4}^{+}$ & Sum & \\
\hline March 28 & 4.1 & 36 & 82 & 122 & 7.9 & 2.5 & 18 & 6.2 & 76 & 111 & 1.1 \\
\hline March 29 & 7.6 & 74 & 178 & 260 & 4.9 & 2.6 & 19 & 10 & 181 & 218 & 1.2 \\
\hline March 30 & 25 & 160 & 300 & 480 & 17 & 7.2 & 77 & 20 & 268 & 390 & 1.2 \\
\hline March 31 & 4.4 & 29 & 64 & 96 & 32 & 4.8 & 32 & 6.8 & 43 & 118 & 0.8 \\
\hline April 1 & 2.6 & 26 & 64 & 93 & 43 & 6.6 & 16 & 7.2 & 37 & 110 & 0.8 \\
\hline April 2 & 4.4 & 20 & 61 & 85 & 30 & 4.7 & 17 & 16 & 29 & 96 & 0.9 \\
\hline April 3 & 5.6 & 32 & 40 & 78 & 5.1 & 5.6 & 6.7 & 9.3 & 59 & 86 & 0.9 \\
\hline April 4 & 3.3 & 19 & 64 & 86 & 11 & 3.3 & 15 & 5.2 & 47 & 82 & 1.1 \\
\hline April 5 & 5.1 & 13 & 40 & 58 & 2.1 & 1.9 & 4.3 & 7.7 & 39 & 55 & 1.1 \\
\hline April 6 & 11 & 140 & 440 & 590 & 10 & 4.5 & 16 & 9.3 & 410 & 450 & 1.3 \\
\hline April 7 & 5.6 & 3.3 & 17 & 26 & 32 & 6.1 & 7.2 & 6.1 & 11 & 62 & 0.4 \\
\hline \multicolumn{12}{|c|}{ Statistics for non-Asian dust event (March 28-April 5) } \\
\hline Mean & 6.9 & 45 & 99 & 150 & 17 & 4.4 & 23 & 9.8 & 87 & 140 & 1.0 \\
\hline
\end{tabular}

Table 5. Ion concentration and anion/cation ratio of coarse particles $\left(\mathrm{PM}_{2-10}\right)$.

\begin{tabular}{|c|c|c|c|c|c|c|c|c|c|c|c|}
\hline & \multicolumn{10}{|c|}{ Equivalent concentration (unit: neq $/ \mathrm{m}^{3}$ ) } & \multirow[t]{3}{*}{ Anion/cation ratio } \\
\hline & \multicolumn{4}{|c|}{ Anion } & \multicolumn{6}{|c|}{ Cation } & \\
\hline & $\mathrm{Cl}^{-}$ & $\mathrm{NO}_{3}^{-}$ & $\mathrm{SO}_{4}^{2-}$ & Sum & $\mathrm{Ca}^{2+}$ & $\mathrm{Mg}^{2+}$ & $\mathrm{K}^{+}$ & $\mathrm{Na}^{+}$ & $\mathrm{NH}_{4}^{+}$ & Sum & \\
\hline March 28 & 25 & 68 & $\begin{array}{l}4 \\
68\end{array}$ & 161 & 65 & 15 & 19 & 27 & 57 & 183 & 0.9 \\
\hline March 29 & 36 & 104 & 103 & 243 & 61 & 17 & 13 & 39 & 75 & 205 & 1.2 \\
\hline March 30 & 27 & 82 & 121 & 230 & 154 & 22 & 36 & 32 & 45 & 290 & 0.8 \\
\hline March 31 & 45 & 167 & 293 & 504 & 504 & 37 & 137 & 50 & 76 & 800 & 0.6 \\
\hline April 1 & 23 & 210 & 292 & 525 & 378 & 33 & 65 & 47 & 114 & 640 & 0.8 \\
\hline April 2 & 73 & 136 & 321 & 530 & 372 & 42 & 39 & 188 & 36 & 680 & 0.8 \\
\hline April 3 & 60 & 101 & 106 & 267 & 111 & 30 & 30 & 65 & 68 & 305 & 0.9 \\
\hline April 4 & 58 & 78 & 130 & 266 & 153 & 22 & 29 & 62 & 47 & 313 & 0.9 \\
\hline April 5 & 41 & 31 & 36 & 108 & 12 & 10 & 5 & 34 & 56 & 118 & 0.9 \\
\hline April 6 & 35 & 80 & 212 & 328 & 202 & 32 & 34 & 44 & 130 & 440 & 0.7 \\
\hline April 7 & 84 & 28 & 88 & 200 & 27 & 45 & 42 & 77 & 64 & 255 & 0.8 \\
\hline \multicolumn{12}{|c|}{ Statistics for non-Asian dust event (March 28-April 5) } \\
\hline Mean & 43 & 109 & 163 & 315 & 201 & 25 & 42 & 61 & 64 & 390 & 0.9 \\
\hline
\end{tabular}

quite different chemical composition and morphological characteristics, hence originate from distinctly different source regions.

\subsection{The first episode dominated by fine aerosol}

At $100 \mu \mathrm{g} / \mathrm{m}^{3}$ the PM10 concentration on March 30, 2002 was lower than the mean value of $112 \mu \mathrm{g} / \mathrm{m}^{3}$ (Table 1) whereas the fine aerosol concentration was the highest and visibility was much deteriorated. As shown in Figure 2, OC and five ionic species but not Ca had a high concentration on March 30. Many fine aerosol constituents had high values: 3.0 times the mean value for sulfate, 3.6 for nitrate, 3.1 for ammonium, 3.4 for potassium (see Table 4 ) and 1.6 for OC. Simultaneous high values for OC and K ion indicate biomass burning emission [27] and that ammonium, sulfate and nitrate are high in biomass burning particles [28]. In China biomass burning occurs mainly as forest fires, agricultural and bio-fuel burning. In particular, agricultural field burning is most frequent in June (summer harvest), late September-early October (autumn harvest) and March-April (spring farming) [29]. Our sampling period corresponded to the spring farming period. 


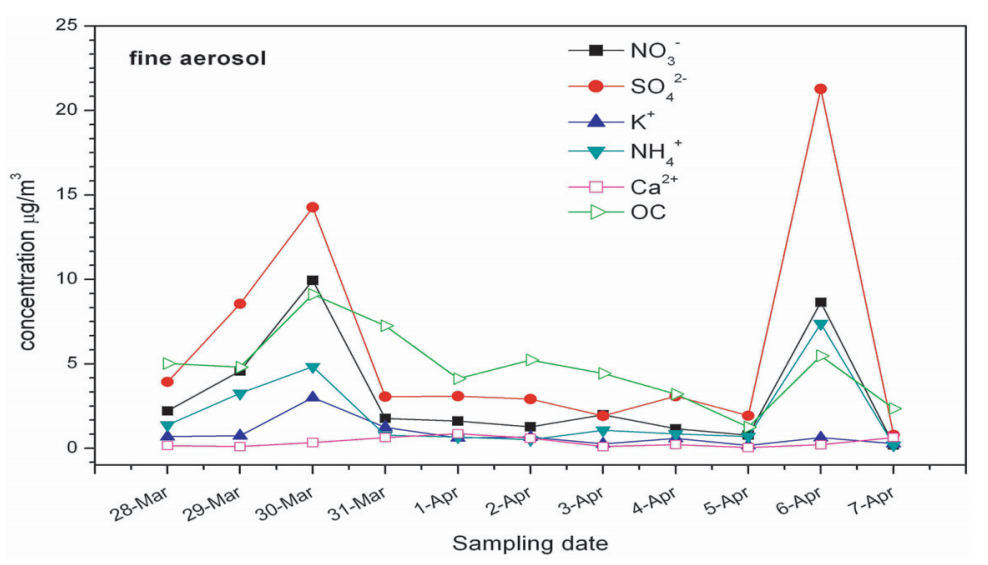

Fig. 2. Variation with time of 6 chemical constituents for the fine particle fraction.

The K/S ratio indicates the proportion of biomass aerosol versus fossil fuel combustion aerosols [30]. $\mathrm{K}^{+}$concentrations on March 30 and 31 were among the highest (see Table 4) and $\mathrm{K} / \mathrm{S}$ ratios were higher than the average value $(0.23)$ for the sampling period. Therefore, this fine aerosol episode can be attributed to the joint contribution of elevated regional particles and biomass burning emissions.

The elemental data (Table 2) show relatively high $\mathrm{Pb}$ and $\mathrm{Zn}$ concentrations on March 30 2002; while the $\mathrm{Pb} / \mathrm{Ti}$ and $\mathrm{Zn} / \mathrm{Ti}$ ratios on that day are 7.1 and 4.4 times higher than the mean ratios. Both aerosol lead content and the ${ }^{206} \mathrm{~Pb} /{ }^{207} \mathrm{~Pb}$ isotope ratio were compared in Figure 3. A negative correlation between aerosol lead content and the ${ }^{206} \mathrm{~Pb} /{ }^{207} \mathrm{~Pb}$ isotope ratio was observed. The correlation coefficient was -0.729 with $\mathrm{p}=0.011$ for the fine fractions and -0.811 with $\mathrm{p}=0.002$ for the coarse fractions. The data revealed a lead pollution event starting from March 30 and lasting for two days featuring an elevated aerosol lead content and an extraordinary low ${ }^{206} \mathrm{~Pb} /{ }^{207} \mathrm{~Pb}$ ratio between 1.111 and 1.119 . Previous studies reported that in Beijing from November 1998 to February 1999 the ${ }^{206} \mathrm{~Pb} /{ }^{207} \mathrm{~Pb}$ ratio was in the range of 1.137-1.158 [18] while from January to November 1998 it was $1.132-1.170$ in Tianjin [31]; these ratios were characteristic values for coal burning emission and soils. In this work it varied by more than $4 \%$ in 11 days, mainly due to the extreme low values of 1.111 on March 30 and 31 , which was never reported before for the atmospheric aerosol in China.

Data of bulk analysis are supported by single particle analysis and are shown in Figure 4 in terms of particle number abundance for the fine aerosol samples. Water-soluble potassium is generally used as a tracer for biomass burning. It is present as $\mathrm{KCl}$ in fresh emissions and is gradually converted into sulfate, bisulfate or nitrate during transport in the air. K-S particles could be detected in SEM-EDX measurements and are used as an indicator for biomass burning emission $[9,32]$. In Figure 4a, K-S particles appeared to be most abundantly present on March 30. $\mathrm{Pb}$ and $\mathrm{Zn}$ containing particles were usually detected with low abundance (Figure $4 \mathrm{~b}$ ). However, they were found more abundantly on March 30. Due to the limited sensitivity of SEM-EDX, Detection Limit ranging from 0.1 to $1 \%$ weight, the lead content in soil or coal fly ash particles is usually too low to be detectable. Therefore, whenever SEM-EDX detected lead containing particles they contain rather high lead contents and most likely originate from industrial nonferrous emission sources. The close association of lead containing and zinc containing particles shown in Figure 4b and elemental data in Tables 2 and 3 also indicate lead oriented non-ferrous industry as their common origin. The low ${ }^{206} \mathrm{~Pb} /{ }^{207} \mathrm{~Pb}$ ratios also corroborate this conclusion: they exclude coal combustion and soil dust as the major source of lead in the samples.

The aerosol episode that started on March 30 showed a simultaneous occurrence of lead pollution and biomass burning (see Figures 2 and 3). The data reported could to be attributed to the same source, presumably the combustion of plant material contaminated by lead containing particle depositions when we follow the results of an earlier study reporting that burning of autumn leaves in urban Beijing was accompanied by increased $\mathrm{Pb}$ concentrations [33]. The 

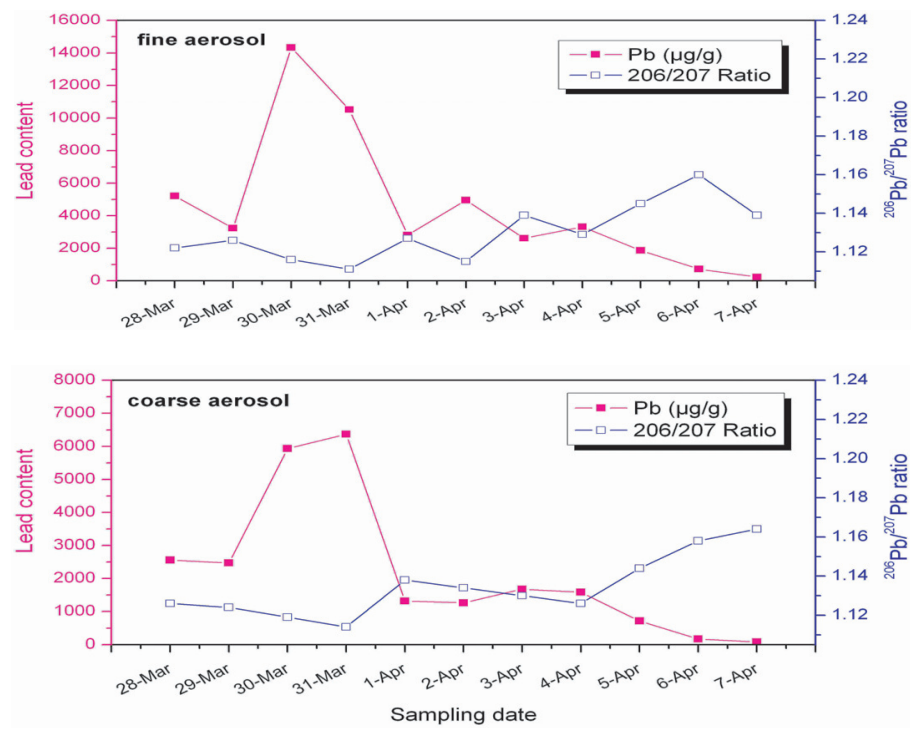

Fig. 3. Variation with time of fine (upper) and coarse (lower) aerosol lead content and isotope abundance ratio.

(a)

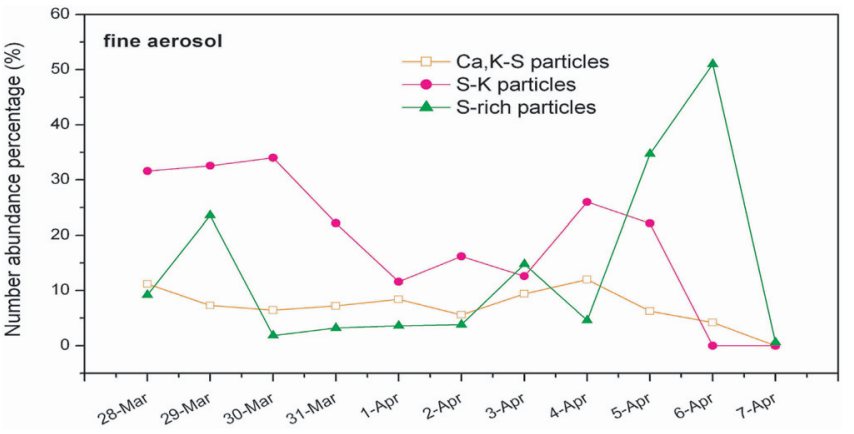

(b)

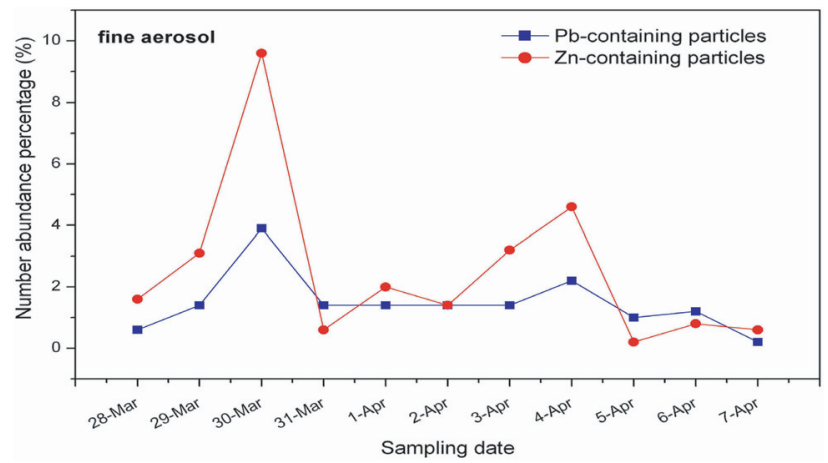

Fig. 4. (a) Variation with time of the number abundance percentage (\%) of S-containing particles in fine particle fraction, using SEM-EDX single particle analysis method, Ca, K-S particles were identified as composite sulfates of calcium and potassium, S-K as composite sulfates of potassium and ammonium, and S-rich as ammonium sulfates; (b) Variation with time of the number abundance of lead-containing and zinc-containing particles for fine particle fraction, using SEM-EDX single particle analysis method. 
The Geopotential Height and Wind fields (2002.3.29 at 1000hpa)
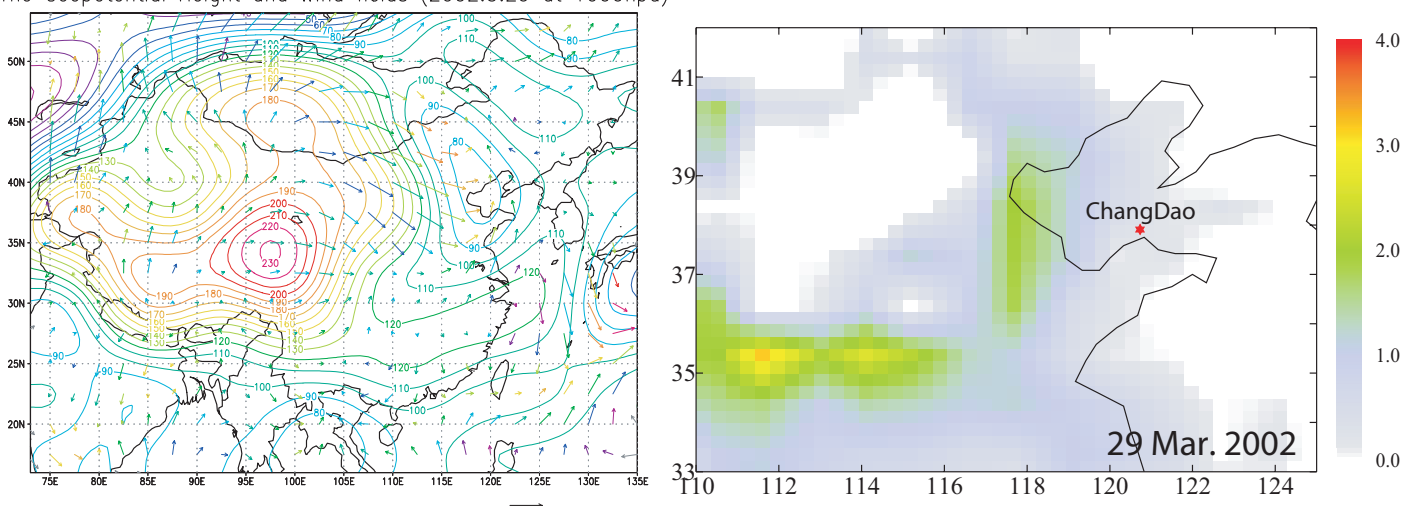

The Geopotential Height and Wind fields (2002.3.30 at $1000 \mathrm{hpa})$
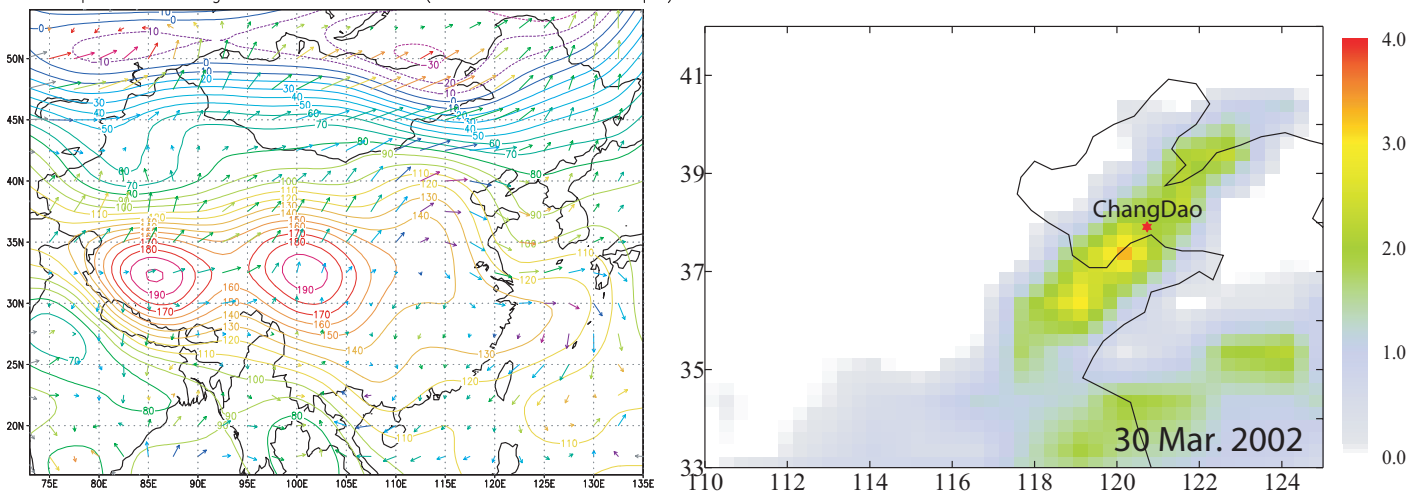

Fig. 5. Wind fields over China at $1000 \mathrm{HPa}$ and Aerosol Index plots over Coastal area of North China on March 29-30, 2002.

aerosol lead and potassium had similar temporal variations and similar enrichment in fine particle fractions as in this work. Particles attached to plant leaves and stems as well as those deposited on the ground for days or weeks could be ejected into air during rather short periods of flaming and smoldering phases of biomass burning.

Figure 5 shows the wind field over China and the aerosol index data from NASA over the coastal area in North China on March 29 and 30, 2002. The western China was under the influence of a strong high pressure while North China was controlled by a low pressure system. Around the Bo Sea the wind field appeared as a cyclone. Also, the aerosol index plots along the southern edge of the low pressure indicated a high aerosol band consistent with the wind circulation pattern. The pollutant cloud moved from inland toward the Bo Sea and on March 29 its center arrived over the border area of three inland provinces (Henan, Shanxi, and Shaanxi), while on the next day it arrived over the sampling site. The remote sensing observations were in agreement with ground level data (Table 1, Figures 2 and 4). Therefore, the fine aerosol episode in coastal area is identified as a long-range transport event. The source region, though not exactly identified, was estimated to be at least $860 \mathrm{~km}$ west of the sampling site.

\subsection{The second aerosol episode dominated by coarse aerosol}

The second aerosol episode lasted for three days (March 31 to April 2) with PM10 concentrations above $200 \mu \mathrm{g} / \mathrm{m}^{3}$, was dominated by coarse particles (Tables 1, 3 and 5 ). Air masses from the Hebei, Shandong, and Jiangsu provinces moved over the Shandong peninsula and arrived at Changdao Island during this period. Wind speeds of up to $7 \mathrm{~m} \cdot \mathrm{s}^{-1}$ produced high concentrations 


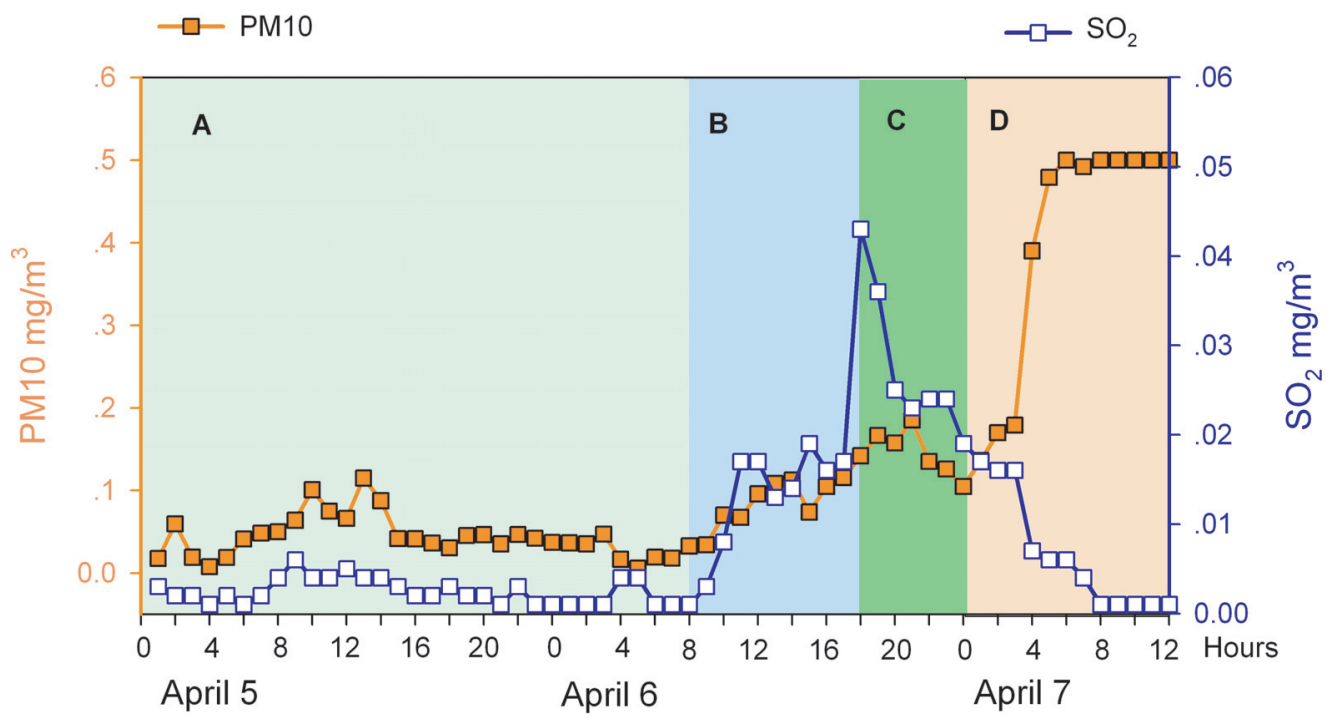

Fig. 6. Hourly records of $\mathrm{PM}_{10}, \mathrm{SO}_{2}$ collected in Yantai city 80 kilometers to the east of Changdao island. (A: low pollution, before 8:00 April 6; B: pollution build-up, 8:00-18:00 April 6; C: pollution clear-out, 18:00-24:00, April 6; D: dust arrival, 0:00-12:00 April 7).

of wind-blown dust. Samples on those days featured a high fraction of coarse particles and were assumed mostly the re-suspension in local or nearby areas.

Particles during this episode showed a high sulfate, nitrate, and Ca concentration in the coarse fraction, whereas sulfate was not so abundantly found in the fine fraction. This was similar with the situation during the Asian Dust events where sulfates were more abundant in the coarse mode than in the fine one after aging processes [34].

When compared with a typical Asian dust sample such as April 7 in Table 3, the Al/Ca ratios were relatively low during the period March 31 to April 2, which implies additional sources of calcium. It was concluded that calcium sulfate particles formed in the desulphurization process in power stations became airborne as primary particles [35]. Indeed, Shandong Province has prominent $\mathrm{SO}_{2}$ emissions in China, mostly due to coal combustion power stations.

This aerosol episode was observed over a wide region in North China and was also reported in other studies [24-26]. The wind blown dust also made a significant contribution to the elevated PM2-10 level, as indicated by the high Al and Ti abundance (see Table 3). However, this episode was not yet the case of a typical Asian Dust event that sweeps all the way from source region to places thousand kilometers away.

\subsection{The third aerosol episode dominated by coarse aerosol}

The last two days of the sampling campaign (April 6 and 7) showed the third episode, a typical Asian Dust event with strong westerly winds. The PM10 concentrations were much higher than the mean value of the earlier nine days, with values of 400 and $600 \mu \mathrm{g} / \mathrm{m}^{3}$ on April 6 and 7 , mostly as coarse particles (see Table 1). The sulfate and nitrate concentrations in the fine fraction were also high, $440 \mathrm{neq} / \mathrm{m}^{3}$ and $140 \mathrm{neq} / \mathrm{m}^{3}$ on April 6 (see Table 4 and Figure 2). The anion to cation ratio of 1.3 indicated the presence of hydrogen ions, thus the acidic nature of the fine fraction. Sulfate and nitrate in the coarse fraction also had high values on April 6 in the coarse fraction. The situation on April 7, 2002 was strikingly different from the previous day. Sulfate and nitrate concentrations dropped by a factor of 26 and 42 for the fine fraction and a factor of 2.4 and 2.9 for the coarse one.

The sulfate speciation was quite different in the fine and the coarse modes and was supposed to be formed by different mechanisms. On April 6, in the fine mode ammonium sulfate and 


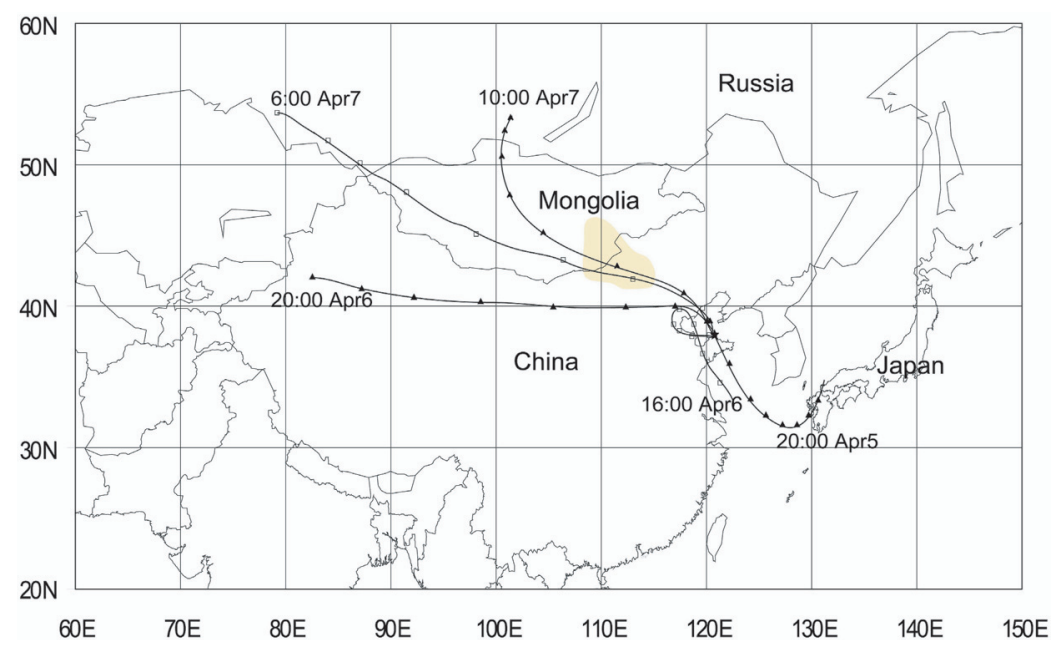

Fig. 7. Two-day backward air trajectories arriving at Changdao island (37.91N, 120.73E) 300 meter above ground level for April 5-7, 2002 with arrival time indications (20 pm-April 5, from southeastern direction, clean marine origin; 16 pm-April 6, being cycled in western Bo Sea area before ending at Changdao island; $16 \mathrm{pm}$ on April 6, from western China; $6 \mathrm{am}$, April 7 and $10 \mathrm{am}$, April 7, both from Mongolia passing over the dust source region (dashed in brown) at the border between Mongolia and China).

bisulfate dominated, accounting for 91 percent of the total fine sulfate (see Figure 4 and the IC data in Tables 4 and 5). The formation of sulfuric acid by the gas-phase oxidation of $\mathrm{SO}_{2}$, and subsequent nucleation processes gave rise to fine sulfates. On the other hand, in coarse mode calcium as well as magnesium, sodium and potassium ions dominated, accounting for 70 percent of the total coarse sulfate, probably as a consequence of the heterogeneous oxidation of $\mathrm{SO}_{2}$ on the surface of mineral dust and sea salt particles [34].

The sulfate partition between fine and coarse modes varied from April 6 to April 7. On April 6 (the front of the dust wave) two third of the total sulfate was found in the fine mode, whereas the next day (during the dust event) 84 percent was within the coarse fraction (Tables 4 and 5).

To identify the source region of this Asian Dust event, air mass backwards trajectories were employed to indicate the air mass movement. TOMS data from the NASA Earth Probe show the source region in the Aerosol Index plots. The atmosphere was clear over North China on April 5, 2002 but the next day the Asian Dust event extended over an area of more than $10,000 \mathrm{~km}^{2}$ along the China-Mongolia border, centered at 43.3N, 110.0E. On April 7 it swept over a large part of lower Northeast China and reached the sampling site. It continued moving across Korea and continued in the northeasterly direction over Sakhalin and then beyond [24].

Wang et al. [26] reported that anthropogenic pollutants, e.g. sulfate and nitrate species might have physical and chemical interactions with mineral dusts such as processes which contribute to mixing on the individual particle level and chemical transformation during the atmospheric transport. On the other hand, it was reported that air masses with anthropogenic pollutants and those dominated by Asian Dust mineral particles traveling as separated consecutive parcels, the actual situation depending on meteorological conditions [36]. The hourly records of PM10 and $\mathrm{SO}_{2}$ collected in Yantai city 80 kilometers to the east of Changdao island are shown in Figure 6 and some selected air mass backward trajectories for Changdao island in Figure 7. It appears that air masses on April 5 and until 8 am on April 6 were of marine origin and PM10 and $\mathrm{SO}_{2}$ levels were low. From 9 am to $17 \mathrm{pm}$ on April 6 air masses made a circular movement over the western Bo Sea before arriving at Changdao island; $\mathrm{PM}$ and $\mathrm{SO}_{2}$ levels were on a rise with a building up of pollutants. From 18 to $23 \mathrm{pm}$, the wind direction suddenly changed to westerly and $\mathrm{PM}$ and $\mathrm{SO}_{2}$ levels decreased, and a clear-out of pollutants occurred. From 
midnight to 4 am on April $7 \mathrm{SO}_{2}$ decreased further while PM quickly increased with the arrival of dust. As the backward trajectories indicate advection then was from northwest direction. This happened about 2 hours earlier for Changdao than for Yantai.

Guo et al. [25] described four stages of an Asian Dust event. When a stage of the clear-out of pollutants and a stage of the arrival of dust are well defined, pollutants and dust are separated and have less chance to mix with each other. Wang et al. [26] also identified this Asian dust event as less mixed when compared with others. These views are supported by the SEM-EDX single particle analysis (Figure 4). On April 6 sulfates were dominated by S-rich particles, mostly ammonium sulfates with composition similar to but concentration levels different than on April 5, a day with an oceanic contribution. IC data also support this (Tables 4 and 5). Abundant sulfates on April 6 with predominantly ammonium sulfates in the fine fraction and calcium and ammonium sulfates in the coarse fraction.

\section{Conclusion}

Overall we conclude that the three aerosol episodes observed over a short period in the spring of 2002 were different in terms of concentrations, size distributions, chemical composition, sulfate speciation, source origins, and source geographic regions. It reveals the complexity of the Asian continental outflow and the importance of its impact to northeastern Asia and northern Pacific regions.

Biomass burning emission is of concern in its own right, but it could be further complicated by intertwining with other pollutants such as industrial lead-containing particles in this study. Vegetation may function as passive sampler for aerosol and other pollutants, resulting in accumulation and amplification effects when once burned.

Sulfates are usually found enriched in fine fraction aerosol, but not necessarily so always. The observation of large portion of sulfates with coarse fraction in this study is in line with modeling studies for aged aerosols.

Mineral particles of Asian Dust event may mix with local pollutants in some Asian Dust events, but may not in others, it depends upon whether there is a clean air parcel coming in between to separate them.

Financial support from the Toyota Foundation (D01-B3-125), the National Basic Research Program of China ( $N^{\circ}$ 2003CB415003), the Flemish-Chinese Bilateral Cooperation Program (BIL01/57), the China NSFC (20177036, 20477042) and the Korean Ministry of Environment (2001-44001-8) are gratefully acknowledged. The authors gratefully acknowledge NASA for providing remote sensing data, the NOAA Air Resources Laboratory (ARL) for the provision of the HYSPLIT transport/dispersion model and the READY website (http://www.arl.noaa.gov/ready.html). Contributions made by Dr. Bing Li, Mr. Shuping Dong, Dr. Qingxian Gao, Dr. Y. S. Ghim, Dr. Z.Y. Cong and Mr. Zhanjun Gao are very much appreciated. Our thanks also go to Dr. Jinhua Guo for her helps in evaluating hourly records of environmental and meteorological data.

\section{References}

1. Y.P. Kim, K.C. Moon, J.H. Lee, N.J. Baik, Atmos. Envir. 33, 2751 (1999)

2. Y. Gao, J.R. Anderson, X. Hua, Atmos. Envir. 41, 7907 (2007)

3. H. Hayami, Atmos. Envir. 39, 2243 (2005)

4. N. Kaneyasu, S. Murayama, J. Geophys. Res. 105, 19, 881 (2000)

5. B. Huebert, T. Bertram, J. Kline, S. Howell, D. Eatough, B. Blomquist, J. Geophys. Res. 109, D19S11 (2004)

6. Z.G. Guo, J.L. Feng, M. Fang, H.Y. Chen, K.H. Lau, Atmos. Envir. 38, 909 (2004)

7. J.L. Feng, Z.G. Guo, C.K. Chan, M. Fan, Atmos. Envir. 41, 1924 (2007)

8. V. Gros, P. Jockel, C.A.M. Brenninkmeijer, T. Rockmann, F. Meinhardt, R. Graul, Atmos. Envir. 36, $2831(2002)$ 
9. J.V. Niemi, H. Tervahattu, H. Vehkamaki, M. Kulmala, T. Koskentalo, M. Sillanpaa, M. Rantamaki, Atmos. Envir. 38, 5003 (2004)

10. J.G. Watson, J.C. Chow, Atmos. Envir. 36, 465 (2002)

11. A. Sapkota, J.M. Symons, J. Kleissl, L. Wang, M.B. Parlange, J. Ondov, P.N. Breysse, G.B. Diette, P.A. Eggleston, T.J. Buckley, Environ. Sci. Technol. 39, 24 (2005)

12. E. Kim, P.K. Hopke, D.M. Kenski, M. Koerber, Environ. Sci. Technol. 39, 4953 (2005)

13. P.K. Hopke, Y. Xie, T. Raunemaa, S. Biegalski, S. Landsberger, W. Maenhaut, P. Artaxo, D. Cohen, Aerosol Sci. Technol. 27, 726 (1997)

14. X.G. Chi, Y.A. Di, S.P. Dong, X.D. Liu, Environ. Monitor. China 15, 11 (1999) (in Chinese)

15. F.K. Duan, X.D. Liu, S.P. Dong, Y.Q. Lu, T. Yu, H. Cachier, Atmos. Envir. 38, 1275 (2004)

16. M. Dan, G.S. Zhuang, X.X. Li, H.R. Tao, Y.H. Zhuang, Atmos. Envir. 38, 3443 (2004)

17. I. Salma, X.G. Chi, W. Maenhaut, Atmos. Envir. 38, 27 (2004)

18. W. Wang, X.D. Liu, Y.Q. Lu, D.F. Guo, Y.W. Li, X.D. Tian, F. Adams, J. Chin. Mass Spectr. Soc. 23, 21 (2002) (in Chinese)

19. B. Raeymaekers, M. Demuynck, W. Dorriné, F. Adams, Int. J. Environ. Anal. Chem. 32, 291 (1988)

20. W.A. Van Borm, F.C. Adams, W. Maenhaut, Characteriz. Indiv. Particl. Antwerp Aerosol. Atmos. Envir. 23, 291 (1989)

21. R.R. Draxler, G.D. Rolph, HYSPLIT (HYbrid Single-Particle Lagrangian Integrated Trajectory), Model access via NOAA ARL READY Website, 2003 http://www . arl.noaa.gov/ready/hysplit4.html

22. N.C. Hsu, J.R. Herman, P.K. Bhartia, C.J. Seftor, O. Torres, A.M. Thompson, J.F. Gleason, T.F. Eck, B.N. Holben, Geophys. Res. Lett. 23, 745 (1996)

23. C.J. Seftor, N.C. Hsu, J.R. Herman, P.K. Bhartia, O. Torres, W. Rose, D. Schneider, N.J. Krotkov, Geophys. Res. 102, 16, 749 (1997)

24. H.J. In, S.U. Park, Atmos. Envir. 37, 4625 (2003)

25. J. Guo, K. Rahn, G. Zhuang, Atmos. Envir. 38, 855 (2004)

26. Y. Wang, G.S. Zhuanga, Y.L. Sun, Z.S. An, Atmos. Envir. 39, 7020 (2005)

27. H. Cachier, J. Ducret, M.P. Bremond, A. Gaudichet, J.P. Lacaux, V. Yoboue, J. Baudet, Global Biomass Burning, edited by J. Levine (MIT Press, Cambridge, 1991), p. 174

28. J.E. Dibb, R.W. Talbot, S.I. Whitlow, M.C. Shipham, J. Winterle, J. Mcconnell, R. Bales, Atmos. Envir. 30, 553 (1996)

29. X.Y. Zheng, X.D. Liu, F.H. Zhao, F.K. Duan, T. Yu, H. Cachier, Sci. China, Ser. B Chem. 48, $481(2005)$

30. Y. Ma, R.J. Weber, Y.N. Lee, D.A. Orsini, K. Maxwell-Meier, D.C. Thornton, A.R. Bandy, A.D. Clarke, D.R. Blake, G.W. Sachse, H.E. Fuelberg, C.M. Kiley, J.H. Woo, D.G. Streets, G.R. Carmichael, J. Geophys. Res. 108, 8816 (2003) doi:10.1029/2002JD003128

31. W. Wang, X.D. Liu, L.W. Zhao, D.F. Guo, X.D. Tian, F. Adams, Sci. Total Environ. 364, 175 (2006)

32. X.D. Liu, P. Van Espen, F. Adams, J. Cafmeyer, W.J. Maenhaut, Atmos. Chem. 36, 135 (2000)

33. R.J. Zhang, M.X. Wang, F.M. Hu, J. Acad. Sci. 19, 75 (2002)

34. C.H. Song, G.R. Carmichael, J. Geophys. Res. 106, 18131 (2001)

35. S. Hoornaert, H. Van Malderen, R. Van Grieken, Sci. Technol. 30, 1515 (1996)

36. D. Zhang, Y. Iwasaka, G. Shi, J. Zang, M. Hu, C.J. Li, Geophys. Res. 110, D06302 (2005) doi:10.1029/2004JD005305 
